\title{
ОКСИДАТИВНИЙ СТРЕС У ТКАНИНАХ ШЛУНКА ЩУРІВ ПРИ МОДЕЛЮВАННІ ГАСТРОПАТІЙ НА ТЛІ НЕСТАЧІ ТА НАДЛИШКУ МЕЛАТОНІНУ
}

Миколаївський національний університет імені В.О.Сухомлинського

Резюме. Дослідження показали, що різні моделі впливів на шлунок щурів, такі, як іммобілізаційний стрес та хімічний гастрит, на тлі нетривалої нестачі та надлишку мелатоніну викликають різну реакцію з боку прооксидантно-антиоксидантної системи (ПАС). При іммобілізаційному стресі мелатонін проявляє гастро-

Вступ. Вперше поняття оксидативний стрес 3'явилося у 80-х роках ХХ століття, коли німецький учений Хельмут Сайс дав таке визначення: «Це дисбаланс прооксидантно-антиоксидантної системи 3 перевагою прооксидантів» [17]. Ключовими поняттями в цій дефініції є прооксиданти та антиоксиданти.

Найбільш активними прооксидантами у живих системах $\epsilon$ вільні радикали та іон-радикали, які містять неспарені електрони на атомах оксигену, нітрогену, сульфуру, хлору: перш за все супероксид-аніон $\left(\mathrm{O}_{2}{ }^{-}{ }^{-}\right)$, що при взаємодії з іншими сполуками перетворюється на пероксид гідрогену $\left(\mathrm{H}_{2} \mathrm{O}_{2}\right)$,що не $є$ радикалом, та дуже реакційноздатний гідроксил-радикал (HО'), синглетний кисень $\left(\mathrm{O}_{2}{ }^{1}\right)$ та пероксинітрит $\left(\mathrm{ONOO}^{-}\right)$. Bci ці форми редукованого оксигену $\left(\mathrm{O}_{2}{ }^{--}, \mathrm{H}_{2} \mathrm{O}_{2}, \mathrm{HO}^{*}\right)$ мають більш високу хімічну активність, ніж молекула кисню, тому вони отримали об'єднуючу назву «активні форми кисню» (АФК) $[12,19]$.

Вплив кисню та АФК призводять до утворення цілого ряду органічних радикалів: R', RO, $\mathrm{ROO}^{\circ}$. Вільний радикал активно реагує із сусідніми молекулами, при цьому утворюється новий радикал, що зумовлює розвиток ланцюгової реакції. Певний стабільний рівень вільнорадикального перекисного окиснення (ВРПО) в організмі підтримується завдяки активності ферментних i неферментних антиоксидантних систем (АОС).

АОС включає неферментні антиоксиданти: токоферол, вітамін А, каротиноїди, убіхінон, аскорбінову кислоту, тіолові сполуки, селенові похідні, трансферин, лактоферин, альбумін, а також ферменти: супероксиддисмутазу (супероксид: супероксид оксидоредуктаза, КФ 1.15.1.1), каталазу (пероксид водню: пероксид водню оксидоредуктаза, КФ (1.11.1.6), глютатіонпероксидазу (глютатіон: пероксид водню оксидоредуктаза, КФ 1.11.1.9) та глутатіонредуктазу (КФ 1.6.4.2), церулоплазмін (ферум II: кисень оксидоредуктаза, КФ 1.16.3.1) (Цебржинський O.I., 2001, Барабой В.А.,2006).

Ціла низка факторів призводить до порушення балансу в прооксидантно-антиоксидантних системах (ПАС) - це стрес, дія хімічних та фізичних факторів, вплив ксенобіотиків тощо, що при(С) О.О. Цвях, Л.Д. Чеботар, 2016

190 протекторну дію, а при моделюванні хімічного гастриту поглиблює оксидативний стрес.

Ключові слова: оксидативний стрес, прооксидантно-антиоксидантна система, шлунок, гастропатії, мелатонін.

зводять до збільшення активності вільнорадикальних процесів і, як наслідок, до збільшення концентрацій первинних та вторинних продуктів перекисного окиснення.

Ще Ганс Сельє (1936 р.) відмітив, що дія на організм численних негативних факторів, незалежно від їх природи та властивостей, буде мати стандартну відповідь, яка проявлятиметься морфологічною тріадою: гіпертрофією кори надниркових залоз; інволюцією тиміко-лімфоцитарної системи (атрофія вилочкової залози і лімфатичних вузлів); утворенням ерозій і виразок у шлунково-кишковому тракті.

При стресі активується гіпоталамогіпофізарно-надниркова система та симпатоадреномедулярна, гормони яких впливають на посилення секреції соляної кислоти, пепсину, призводять до гіпертонусу шлунка, ішемії судин шлунка. Все це спричиняє внутрішньошлунковий протеоліз та пошкодження слизової оболонки [3, 9, 13 ]. Крім того стрес, у тому числі і іммобілізаційний, призводить до посилення вільнорадикального перекисного окиснення (ВРПО), а як наслідок - до окиснювального порушення цілісності тканин, що також призводить до виникнення гастродоуденальних ерозій та виразок [7,14]. Зміщення рівноваги в бік вільнорадикального перекисного окиснення із зростанням концентрацій продуктів пероксидації і $є$ оксидативним стресом, що врешті-решт призводить до порушення цілісності тканин. Тому в науковій літературі з'являється нове, більш глибоке, визначення терміну «оксидативний стрес»: «це тимчасове чи постійне підвищення (від стаціонарного) рівня АФК, які порушують клітинну цілісність та метаболізм, включно з тим, що відбувається за участі АФК, що веде до окисної модифікації клітинних компонентів, яке при суттєвому дисбалансі у ПАС може призвести до клітинної загибелі у вигляді некрозу чи апоптозу» (Лущак, 2015).

У сучасних дослідженнях необхідно зосередитись на питанні «що може скорегувати гострий та хронічний оксидативний стрес». Для профілактики ВРПО та корекції патологій, що були викликані вільними радикалами в сучасній медич- 
ній практиці, використовують цілу низку антиоксидантів.

Таким стресопротектором, стимулятором імунної системи, геро- та канцеропротектором, антиоксидантом (AO) є мелатонін, він здатний позитивно впливати на стан шлунково-кишкового тракту та здійснювати антиульцерогенний ефект $[1,15,18,20]$. Механізми антиоксидантної дії мелатоніну пов'язані зі здатністю безпосередньо знешкоджувати вільні радикали, а також виступати непрямим антиоксидантом, активуючи антиоксидантні ферменти: супероксиддисмутазу (СОД), глютатіонпероксидазу (ГПО) [2].

Мета дослідження. Встановити зміни показників ПАС при моделюванні гастропатій на тлі нестачі та надлишку мелатоніну та з'ясувати чи здійснює мелатонін гасторопротективну дію при різних видах гастропатій.

Матеріал і методи. Дослідження проводили на 90 самцях щурів лінії Wistar. Утримання тварин та експерименти проводилися відповідно до положень «Свропейської конвенції про захист хребетних тварин, які використовуються для експериментів та інших наукових цілей» (Страсбург, 1985) та «Загальних етичних принципів експериментів на тваринах», ухвалених Першим національним конгресом з біоетики (Київ, 2001).

Гіпомелатонінемію (нестача мелатоніну) моделювали за методом, описаним В.М.Гуралюком (2008) [5], цілодобовим освітленням терміном 10 діб. Оскільки мелатонін в епіфізі синтезується тільки в умовах темряви, ми допустили, що ця модель частково відтворює гіпомелатонінемію, враховуючи, що відбувається цілодобовий синтез гормону APUD-системою. Відомо, що для білих щурів достатньо $0,0005 \mathrm{MB} / \mathrm{cm}^{2}$ потужності світла, щоб знизити кількість синтезованого мелатоніну [10].

Максимально допустима доза мелатоніну при одноразовому введенні, відповідно до джерел літератури $[4,8]$, складає 5 мг/кг маси тіла. В експерименті гіпермелатонінемію відтворювали шляхом уведення мелатоніну в дозі 1 мг/кг на добу терміном 10 діб.

В експериментах моделювали два варіанти гастропатій: стрес-виразка шлунка за Сельє та утворення ерозій на тлі введення оцтової кислоти. За 24 години до моделювання гастропатій тваринам не давали їжі, але був вільний доступ до води, оскільки голодування внаслідок активації анаеробного гліколізу призводить до зниження рівня факторів захисту в слизовій оболонці шлунка. За Сельє стрес-виразку моделювали шляхом іммобілізації тварин у тісних пеналах протягом трьох годин. У механізмі генезу моделі «стрес-виразки» провідне місце посідає нейрогуморальний фактор, тому дана модель $є$ найбільш адекватною серед швидко відтворюваних «гострих» експериментальних виразок (Заводская И.С., Морева Е.В.,1981). Другий варіант гастропатії моделювали введенням розчину $10 \%$ оцтової кислоти зондово per os під легким наркозом одноразово. Гастропатії моделювали на дев 'ятий день експерименту, а на десятий проводили евтаназію шляхом кровопускання під гексаналовим наркозом за вимогами біоетики. Для подальшої роботи проводили відбір шлунків.

Після макроскопічного дослідження оцінювали ступінь ерозивно-виразкового пошкодження слизової оболонки шлунка. На слизовій оболонці шлунка обчислювали кількість виразок, середнє число деструкцій на одну тварину в групі, відсоток тварин із виразками в групі (Хаджай Я.И. и др., 1962) та підраховували індекс Паулса (Pauls F., Wick A.M., Mac Key E.M. et al., 1947; Добряков Ю.И., 1978) $[6,11,16]$ за формулою, що наведена нижче.

Також розраховували противиразкову активність - ПВАмт (відношення індексу Паулса контролю до індексу Паулса дослідної групи).

У гомогенаті шлунка визначали концентрації первинних (дієнові кон'югати (ДК) за методом Стальной И.Д.) та вторинних (тіобарбітурова кислота(ТБК)-активні продукти) за методом Стальной И.Д., Гаришвили Т.Г.) продуктів вільнорадикального перекисного окиснення. Також визначали в гомогенаті шлунка активності каталази за методом Королюка М.А., Іванової Л.І., глютатіонпероксидази (ГПО) за методом Пахомової В.О., супероксиддисмутази (СОД) за методом Чевари С., Чаба И., загальну протеолітичну активність (ЗПА) за Куниц (Kunitz).

Використовували наступні методи статистичного аналізу: перевірка нормальності розподілу за допомогою критерію Шапіро-Уілка, достовірність різниці між середніми величинами кожного 3 біохімічних параметрів в досліджуваних групах визначали за допомогою t-критерію Стьюдента. Статистичний аналіз проводили з використанням комп'ютерної програми Microsoft Office Excel 2007.

Результати досліджень та їх обговорення. Як показали наші дослідження вміст первинних продуктів перекисного окиснення ліпідів та ТБКактивних продуктів при моделюванні іммобілізаційного стресу на тлі 10 -добової нормо-, гіпо- і гіпермелатонінемії змінюється, відбуваються зміни і в роботі ферментативної ланки антиоксидантного захисту (табл. 1).

У стресових умовах у тварин виник гострий оксидативний стрес, що характеризувався різкими змінами показників ПАС: концентрація дієнових кон'югатів у гомогенатах тканин шлунка зросла в 1,7 раза порівняно 3 інтактною групою

\section{$\frac{n \text { сер. число деструкційна } 1 \text { тварину }}{100} \times \%$ тварин із виразками}

Формула підрахунку індекса Паулса 
Таблиця 1

Зміни деяких показників ПАС при моделюванні іммобілізаційного стресу на тлі нестачі та надлишку мелатоніну, $(\mathrm{M} \pm \mathbf{m})$

\begin{tabular}{|c|c|c|c|c|c|c|}
\hline \multirow{3}{*}{ Показники } & \multicolumn{6}{|c|}{ Умови експерименту } \\
\hline & \multicolumn{2}{|c|}{$\begin{array}{l}\text { Природне освітлення } \\
\text { Нормомелатонінемія }\end{array}$} & \multicolumn{2}{|c|}{$\begin{array}{l}\text { Постійне освітлення } \\
\text { Гіпомелатонінемія }\end{array}$} & \multicolumn{2}{|c|}{$\begin{array}{c}\text { Природне освітлен- } \\
\text { ня+уведення мелатоніну } \\
\text { Гіпермелатонінемія }\end{array}$} \\
\hline & $\begin{array}{l}\text { За відсутнос- } \\
\text { ті стресу } \\
\text { (Інтакт) }(\mathrm{n}=8)\end{array}$ & $\begin{array}{l}\text { При стресі } \\
(\mathrm{n}=8)\end{array}$ & $\begin{array}{c}\text { За відсутнос- } \\
\text { ті стресу } \\
(\mathrm{n}=8)\end{array}$ & $\begin{array}{l}\text { При стресі } \\
(\mathrm{n}=8)\end{array}$ & $\begin{array}{l}\text { За відсут- } \\
\text { ності } \\
\text { стресу } \\
(\mathrm{n}=8)\end{array}$ & $\begin{array}{l}\text { При стресі } \\
(\mathrm{n}=8)\end{array}$ \\
\hline ДК ммоль/кг & $6,438 \pm 0,365$ & $\begin{array}{c}11,01 \pm \\
0,513^{* * *}\end{array}$ & $6,75 \pm 0,571$ & $9,26 \pm 0,371 * * * \bullet$ & $\begin{array}{l}4,431 \pm \\
0,589 *\end{array}$ & $8,699 \pm 0,498 * *$ \\
\hline $\begin{array}{l}\text { ТБК-активні } \\
\text { продукти, } \\
\text { мкмоль/кг }\end{array}$ & $7,821 \pm 0,26$ & $19,81 \pm 2,68 * *$ & $8,014 \pm 0,34$ & $13,51 \pm 1,66^{* *}$ & $\begin{array}{c}9,23 \pm \\
1,54\end{array}$ & $13,4 \pm 2,35^{*}$ \\
\hline $\begin{array}{c}\text { Активність } \\
\text { СОД, ум.од./Г }\end{array}$ & $0,285 \pm 0,05$ & $0,214 \pm 0,05$ & $0,143 \pm 0,033^{*}$ & $0,182 \pm 0,016$ & $\begin{array}{c}0,219 \pm \\
0,027\end{array}$ & $0,168 \pm 0,031$ \\
\hline $\begin{array}{c}\text { Активність } \\
\text { каталази, } \\
\text { мкат/кг } \\
\end{array}$ & $2,559 \pm 0,074$ & $2,09 \pm 0,09 * *$ & $\begin{array}{c}2,113 \pm 0,106 \\
* *\end{array}$ & $2,116 \pm 0,076 * * *$ & $\begin{array}{l}2,895 \pm \\
0,131^{*}\end{array}$ & $\begin{array}{c}2,195 \pm 0,042 * * \\
*\end{array}$ \\
\hline $\begin{array}{l}\text { Активність } \\
\text { ГПО мкат/кг }\end{array}$ & $5,46 \pm 0,308$ & $5,07 \pm 0,293$ & $4,64 \pm 0,312$ & $4,93 \pm 0,442$ & $\begin{array}{c}4,11 \pm \\
0,302 * *\end{array}$ & $4,41 \pm 0,276^{*}$ \\
\hline
\end{tabular}

Примітка. * **,*** - різниця між вибірковими середніми вірогідна на рівні значущості відповідно $\rho \leq 0,05, \rho \leq 0,01$, $\rho \leq 0,001$ порівняно з інтактною групою; ' - $\quad$ - різниця між вибірковими середніми вірогідна на рівні значущості відповідно $\rho \leq 0,05, \rho \leq 0,01, \rho \leq 0,001$ порівняно зі стрес-контролем

Таблиця 2

Морфологічні зміни в слизовій оболонці шлунка білих шурів при моделюванні іммобілізаційного стресу на 10-ту добу нормо-, гіпо- та гіпермелатонінемії, $(\mathrm{M} \pm \mathbf{m})$

\begin{tabular}{|c|c|c|c|c|c|c|}
\hline \multirow{3}{*}{ Показники } & \multicolumn{6}{|c|}{ Умови експерименту } \\
\hline & \multicolumn{2}{|c|}{$\begin{array}{l}\text { Природне освітлення } \\
\text { Нормомелатонінемія }\end{array}$} & \multicolumn{2}{|c|}{$\begin{array}{c}\text { Постійне освітлення } \\
\text { Гіпомелатонінемія }\end{array}$} & \multicolumn{2}{|c|}{$\begin{array}{c}\text { Природне освітлення+ уве- } \\
\text { дення мелатоніну } \\
\text { Гіпермелатонінемія }\end{array}$} \\
\hline & $\begin{array}{c}\text { За відсутнос- } \\
\text { ті } \\
\text { стресу } \\
\text { (Інтакт) }(\mathrm{n}=8)\end{array}$ & $\begin{array}{l}\text { При стресі } \\
\quad(\mathrm{n}=8)\end{array}$ & $\begin{array}{c}\text { За відсутнос- } \\
\text { ті } \\
\text { стресу }(\mathrm{n}=8)\end{array}$ & $\begin{array}{l}\text { При стресі } \\
\quad(\mathrm{n}=8)\end{array}$ & $\begin{array}{c}\text { За відсутнос- } \\
\text { ті } \\
\text { стресу }(\mathrm{n}=8)\end{array}$ & $\begin{array}{l}\text { При стресі } \\
(\mathrm{n}=8)\end{array}$ \\
\hline Частота уражень, \% & 12,5 & $87,5 * * *$ & 0 & $100 * * *$ & $25^{* *}$ & $62,5 * *$ \\
\hline $\begin{array}{c}\text { Середня к-ть деструкцій } \\
\text { на } 1 \text { щура }\end{array}$ & 0,25 & $9,63 * * *$ & 0 & $13,25 * * *$ & $0,5^{* *}$ & $3,38 * *$ \\
\hline $\begin{array}{c}\text { Середній ступінь вираз- } \\
\text { ки (СВ) у групі }\end{array}$ & 0,125 & $1,5 * * *$ & 0 & $2,125 * * *$ & $0,375 * *$ & $1 * * *$ \\
\hline Індекс Паулса (ІП) & 0,031 & $8,42 * * *$ & 0 & $13,25 * * *$ & $0,125 * * *$ & $2,11 * * *$ \\
\hline
\end{tabular}

Примітка. *, **,*** - різниця між вибірковими середніми вірогідна на рівні значущості відповідно $\rho \leq 0,05, \rho \leq 0,01$, $\rho \leq 0,001$ порівняно з інтактною групою

(на $71,02 \% \quad(\rho=0,001))$; концентрація ТБКактивних продуктів у гомогенаті тканин шлунка щурів зросла в 2,5 раза порівняно 3 інтактом $(\rho=0,001)$; спостерігалося зменшення активності ферментативної антиоксидантної ланки - активність СОД знизилася несуттєво (на 24,9\%), активність каталази знизилася (на $18,3 \%(\rho \leq 0,01)$ ), активність ГПО знизилася незначно (на $7 \%$ ).
При іммобілізаційному стресі на тлі нестачі мелатоніну також спостерігався гострий оксидативний стрес: концентрація ДК у гомогенатах тканин шлунка зросла порівняно з інтактом (на $43,8 \%(\rho=0,001)$, але цей показник менший, ніж при стрес-контролі (на 15,9\% $(\rho \leq 0,05))$; концентрація ТБК-активних продуктів у гомогенаті тканин шлунка щурів зросла в 1,7 раза порівняно 3 
інтактом $(\rho \leq 0,01)$, але цей показник несуттєво менший ніж при стрес-контролі; також спостерігалося зменшення активності ферментативної антиоксидантної ланки - активність СОД несуттєво знизилася порівняно з інтактом (на $36,1 \%$ ); активність каталази знизилася (на 17,3 \% $(\rho=0,001))$; активність ГПО знизилася несуттєво (на 9,7 \%) порівняно з інтактом.

При іммобілізаційному стресі на тлі введення мелатоніну per os у дозі 1 мг/кг також спостерігався гострий оксидативний стрес: рівень ДК при гіпермелатонінемії зріс порівняно 3 інтактною групою (на $31,2 \%(\rho \leq 0,01))$, але концентрація була менша на $21 \%$ порівняно із стресконтрольною групою $(\rho=0,01)$ і незначно меншим, ніж при стресі з гіпомелатонінемією; концентрація ТБК-активних продуктів у гомогенаті тканин шлунка зросла в 1,7 раза (на $71 \%$ $(\rho \leq 0,05))$, але цей показник був несуттєво менший, ніж у стрес-контролі (на $32,4 \%$ ); активність СОД несуттєво знизилася порівняно з інтактом (на 41,1 \%) та практично не відрізнялася від активності при стресі та при стресі з гіпомелатонінемією; активність каталази знизилася (на 14,2 \% $(\rho=0,001))$, але також практично не відрізнялася від активності при стресі та при стресі з гіпомелатонінемією; активність ГПО також знизилася (на 19,2 \% $(\rho \leq 0,05))$ порівняно з інтактом, а також виявилася нижчою, ніж у стрес-контролі (на $13 \%)$.

Наші дослідження показали зростання тяжкості виразкового процесу в шлунку щурів при моделюванні іммобілізаційного стресу: зростає частота уражень, збільшується середня кількість деструкцій на одну тварину, зростає середній ступінь виразки в групі, збільшується індекс Паулса (табл. 2), а також спостерігалося значне погіршення всіх показників при іммобілізаційному стресі на тлі гіпомелатонінемії.

Наші розрахунки противиразкової активності (відношення індексу Паулса групи стресконтролю до індексу Паулса групи, де моделювали іммобілізаційний стрес на тлі гіпермелатонінеміi) показали, що мелатонін проявляв гастропротекторну активність.

Аналізуючи отримані дані, можна зазначити, що профілактичне введення мелатоніну не запобігло виникненню гострого оксидативного стресу в цій моделі гастропатії, але іммобілізаційний стрес спричинив меншу пошкоджувальну дію на СОШ.

Але як показали наші дослідження, в іншій моделі гастропатії, а саме при хімічному гастриті, коливання показників прооксидантної ланки

Таблиця 3

Зміни деяких показників ПАС при моделюванні хімічного гастриту на тлі нестачі та надлишку мелатоніну, $(\mathrm{M} \pm \mathrm{m})$

\begin{tabular}{|c|c|c|c|c|c|c|}
\hline \multirow{3}{*}{$\begin{array}{c}\text { Показни- } \\
\text { ки }\end{array}$} & \multicolumn{6}{|c|}{ Умови експерименту } \\
\hline & \multicolumn{2}{|c|}{$\begin{array}{l}\text { Природне освітлення } \\
\text { Нормомелатонінемія }\end{array}$} & \multicolumn{2}{|c|}{$\begin{array}{c}\text { Постійне освітлення } \\
\text { Гіпомелатонінемія }\end{array}$} & \multicolumn{2}{|c|}{$\begin{array}{c}\text { Природне освітлення+ уведення } \\
\text { мелатоніну } \\
\text { Гіпермелатонінемія }\end{array}$} \\
\hline & $\begin{array}{c}\text { За відсутнос- } \\
\text { ті впливу на } \\
\text { СОШ }(\mathrm{n}=7)\end{array}$ & $\begin{array}{c}\text { При моделю- } \\
\text { вав-нні хіміч- } \\
\text { ного гастриту } \\
(\mathrm{n}=7) \\
\end{array}$ & $\begin{array}{c}\text { За відсутнос- } \\
\text { ті впливу на } \\
\text { СОШ } \\
(\mathrm{n}=7) \\
\end{array}$ & $\begin{array}{c}\text { При моделю- } \\
\text { вав-нні хіміч- } \\
\text { ного гастриту } \\
(\mathrm{n}=7) \\
\end{array}$ & $\begin{array}{c}\text { За відсутнос- } \\
\text { ті впливу на } \\
\text { СОШ } \\
(\mathrm{n}=7) \\
\end{array}$ & $\begin{array}{c}\text { При моделю- } \\
\text { вав-нні хіміч- } \\
\text { ного гастриту } \\
(\mathrm{n}=7) \\
\end{array}$ \\
\hline $\begin{array}{c}\text { ДК } \\
\text { ммоль/кг }\end{array}$ & $6,305 \pm 0,102$ & $\begin{array}{l}4,617 \pm 0,206^{*} \\
*\end{array}$ & $\begin{array}{c}7,812 \pm 0,314 * \\
* *\end{array}$ & $\begin{array}{c}14,42 \pm 1,311 * \\
* * \cdots+\end{array}$ & $\begin{array}{c}7,759 \pm 0,177 * \\
* * \cdots\end{array}$ & $10,33 \pm 0,363 * * *$ \\
\hline $\begin{array}{c}\text { ТБК- } \\
\text { активні } \\
\text { продукти, } \\
\text { мкмоль/ } \\
\text { кг } \\
\end{array}$ & $5,769 \pm 0,228$ & $\begin{array}{c}7,359 \pm 0,422 * \\
*\end{array}$ & $\begin{array}{c}19,5 \pm 1,269 * * \\
* \mathbf{m}\end{array}$ & $\begin{array}{c}12,82 \pm 0,759 * \\
* * \cdots\end{array}$ & $\begin{array}{c}95,88 \pm 0,824 * \\
* * \cdots\end{array}$ & $100,6 \pm 1,063 * * *$ \\
\hline $\begin{array}{c}\text { Актив- } \\
\text { ність } \\
\text { СОД, } \\
\text { ум.од./г }\end{array}$ & $0,644 \pm 0,032$ & $0,373 \pm 0,096^{*}$ & $0,56 \pm 0,065^{\mathbf{I}}$ & $\begin{array}{c}0,264 \pm 0,048 * \\
* *\end{array}$ & $\begin{array}{c}1,161 \pm 0,026^{*} \\
* * \cdots\end{array}$ & $1,147 \pm 0,037 * * *$ \\
\hline $\begin{array}{c}\text { Актив- } \\
\text { ність } \\
\text { каталази, } \\
\text { мкат/кг } \\
\end{array}$ & $2,1 \pm 0,088$ & $2,166 \pm 0,084$ & $1,542 \pm 0,205^{* \bullet}$ & $\begin{array}{c}1,424 \pm 0,164 * \\
*\end{array}$ & $1,928 \pm 0,016$ & $1,788 \pm 0,094 *$ \\
\hline $\begin{array}{c}\text { Актив- } \\
\text { ність } \\
\text { ГПО } \\
\text { мкат/кг }\end{array}$ & $5,69 \pm 0,172$ & $\begin{array}{c}7,88 \pm 0,251 * * \\
*\end{array}$ & $\begin{array}{c}7,32 \pm 0,263 * * \\
*\end{array}$ & $8,14 \pm 0,09 * * *$ & $\begin{array}{c}7,31 \pm 0,088^{* *} \\
*\end{array}$ & $7,98 \pm 0,145^{* * *}$ \\
\hline
\end{tabular}

Примітка. * ***** - різниця між вибірковими середніми вірогідна на рівні значущості відповідно $\rho \leq 0,05, \rho \leq 0,01$, $\rho \leq 0,001$ порівняно з інтактною групою ; $\mathbf{m}$ різниця між вибірковими середніми вірогідна на рівні значущості відповідно $\rho \leq 0,01, \rho \leq 0,001$ порівняно з групою з хімічним гастритом 
Таблиця 4

Морфологічні зміни в слизовій оболонці шлунка білих щурів при моделюванні хімічного гастриту на 10-ту добу нормо-, гіпо- та гіпермелатонінемії, $(\mathrm{M} \pm \mathrm{m})$

\begin{tabular}{|c|c|c|c|c|c|c|}
\hline \multirow{2}{*}{ Показники } & \multicolumn{5}{|c|}{ Умови експерименту } \\
\cline { 2 - 6 } & \multicolumn{2}{|c|}{$\begin{array}{c}\text { Природне освітлення } \\
\text { Нормомелатонінемія }\end{array}$} & \multicolumn{2}{|c|}{$\begin{array}{l}\text { Постійне освітлення } \\
\text { Гіпомелатонінемія }\end{array}$} & $\begin{array}{c}\text { Природне освітлення+ уведен- } \\
\text { ня мелатоніну } \\
\text { Гіпермелатонінемія }\end{array}$ \\
\cline { 2 - 7 } & $\begin{array}{c}\text { За відсутнос- } \\
\text { ті впливу на } \\
\text { СОШ (n=7) } \\
\text { ванні хіміч- } \\
\text { ного гастри- } \\
\text { ту (n=7) }\end{array}$ & $\begin{array}{c}\text { 3а відсутнос- } \\
\text { ті впливу на } \\
\text { СОШ } \\
(\mathrm{n}=7)\end{array}$ & $\begin{array}{c}\text { При моделю- } \\
\text { ванні хіміч- } \\
\text { ного гастри- } \\
\text { ту (n=7) }\end{array}$ & $\begin{array}{c}\text { 3а відсутнос- } \\
\text { ті впливу на } \\
\text { СОШ } \\
(\mathrm{n}=7)\end{array}$ & $\begin{array}{c}\text { При монні хімічн- } \\
\text { гастриту (n=7) }\end{array}$ \\
\hline Частота уражень, \% & 0 & $100^{* * *}$ & $100^{* * *}$ & $100^{* * *}$ & $57,14 * * *$ & $100^{* * *}$ \\
\hline $\begin{array}{c}\text { Середня к-ть деструк- } \\
\text { цій на 1 щура (СКД) }\end{array}$ & 0 & $3,43 * * *$ & $5,43 * * *$ & $7 * * *$ & $3 * * *$ & $13 * * *$ \\
\hline $\begin{array}{c}\text { Середній ступінь де- } \\
\text { струкцій (ССД) у групі }\end{array}$ & 0 & $1,57 * * *$ & $1,71 * * *$ & $2,29 * * *$ & $0,86 * * *$ & $2,57 * * *$ \\
\hline Індекс Паулса (ІП) & 0 & $3,43 * * *$ & $5,43 * * *$ & $7 * * *$ & $1,71 * * *$ & $13 * * *$ \\
\hline
\end{tabular}

Примітка. *, **,*** - різниця між вибірковими середніми вірогідна на рівні значущості відповідно $\rho \leq 0,05, \rho \leq 0,01$, $\rho \leq 0,001$ порівняно з інтактною групою

та антиоксидантних ферментів проходять у дещо іншому ключі (табл. 3).

В умовах моделювання хімічного гастриту у тварин не виникає гострого оксидативного стресу: концентрація дієнових кон'югатів у гомогенатах тканин шлунка дещо знизилася порівняно 3 інтактною групою (на 26,8 \% $(\rho=0,01)$ ); концентрація ТБК-активних продуктів у гомогенатах тканин шлунків щурів зросла порівняно $з$ інтактом (на 27,6 \% $(\rho=0,01))$; активність СОД знизилася у 1,7 раза $(\rho \leq 0,05)$; активність каталази практично не змінилася; а активність ГПО зросла (на $38,5 \%$ $(\rho=0,001))$.

При моделюванні хімічного гастриту на тлі 10-добової гіпомелатонінемії спостерігався гострий оксидативний стрес: концентрація дієнових кон'югатів у гомогенатах тканин шлунка зросла у 2,3 раза $(\rho=0,001)$; концентрація ТБК-активних продуктів у гомогенатах тканин шлунка щурів зросла у 2,2 раза порівняно 3 інтактом $(\rho=0,001)$; спостерігалося зменшення активності ферментативної антиоксидантної ланки - активність СОД знизилася порівняно 3 інтактом у 2,4 раза $(\rho=0,001)$, та виявилася меншою, ніж у групі 3 хімічним гастритом (на 29,2\%); активність каталази також знизилася порівняно 3 інтактом (на $32,2 \%(\rho=0,01))$, також виявилася меншою, ніж у групі 3 хімічним гастритом (на $34,3 \%(\rho=0,001)$ ); i тільки активність ГПО зросла порівняно і $з$ інтактом (на 43,1 \% $(\rho=0,001))$ та практично не відрізнялася від групи, де моделювали хімічний гастрит.

При моделюванні хімічного гастриту на тлі 10-добової гіпермелатонінемії рівень вмісту первинних та вторинних продуктів виявився також високим: так, концентрація ДК зросла порівняно 3 інтактом (на $63,8 \%(\rho=0,001)$ ), але порівняно 3 групою, де моделювали гастрит на тлі гіпомелатонінемії, знизилася (на $28,4 \%(\rho \leq 0,05))$; концентрація ТБК-активних продуктів у гомогенатах тканин шлунка щурів зросла в 17,4 раза ( $\rho=0,001)$, а порівняно 3 групою, де моделювали гастрит на тлі гіпомелатонінемії - зросла в 7,9 раза $(\rho=0,001)$. Що стосується антиоксидантної ланки, то спостерігалося зростання активності СОД порівняно 3 інтактом в 1,8 раза $(\rho=0,001)$, порівняно з групою з хімічним гастритом у 3 рази $(\rho=0,001)$, порівняно з групою з хімічним гастритом на тлі гіпомелатонінемії в 4,4 раза $(\rho=0,001)$. Активність каталази виявилася меншою, ніж в інтакті (на $14,9 \%(\rho \leq 0,05))$ та виявилася трохи більшою, ніж у групі з хімічним гастритом на тлі гіпомелатонінемії ( на $16 \%$ ). Активність ГПО виявилася більшою, ніж в інтакті (на $40,3 \%(\rho=0,001))$, та практично не відрізнялася від активності в групі з хімічним гастритом і у групі з гастритом на тлі гіпомелатонінемії.

Як видно з табл.4, при моделюванні хімічного гастриту спостерігається зростання тяжкості виразкового процесу в шлунку щурів порівняно 3 інтактом: зростає частота уражень, збільшується середня кількість деструкцій на одну тварину, зростає середній ступінь деструкцій у групі, збільшується індекс Паулса. При нестачі мелатоніну та моделюванні хімічного гастриту погіршилися всі показники, але при гіпермелатонінемії та хімічному гастриті показники виявилися ще гіршими, порівняно 3 групою 3 хімічним гастритом: середня кількість деструкцій виросла в 3,8 раза, виріс середній ступінь виразки в 1,6 раза, індекс Паулса виріс у 3,8 раза.

Також розраховували противиразкову активність мелатоніну ПВАмт (відношення індексу Паулса у групі з моделлю хімічного гастриту до індексу Паулса у групі, де моделювали хімічний гастрит на тлі гіпермелатонінемії): мелатонін, у цій моделі гастропатії, не виявив своєї активності, оскільки (за Pauls, 1947) ПВАмт повинен бути більше двох одиниць. 


\section{Висновки}

1. При моделюванні гастропатії шляхом іммобілізаційного стресу в тканинах шлунка щурів виникає гострий оксидативний стрес.

2. При моделюванні хімічного гастриту спостерігалася відсутність суттєвих змін показників прооксидантно-антиоксидантної системи, що означає відсутність гострого оксидативного стреcy.

3. Уведення мелатоніну в дозі 1 мг/кг на добу терміном 10 діб зумовило гастропротекторний ефект у групі, де моделювали іммобілізаційний стрес.

4. Уведення мелатоніну в дозі 1 мг/кг на добу терміном 10 діб у групі, де моделювали хімічний гастрит, не виявило гастропротекторної дії, а концентрація продуктів вільнорадикального перекисного окиснення виявилася більшою, ніж у всіх інших дослідних групах, що свідчить про гострий оксидативний стрес.

5. Реакції прооксидантно-антиоксидантної системи шлунка щурів за різних моделей гастропатій різняться, що свідчить про різні механізми адаптацій цієї системи до дії негативних чинників.

Перспективи подальших досліджень. Доцільними є подальші дослідження реакцій прооксидантно-антиоксидантної системи шлунка в умовах оксидативного стресу на тлі тривалої нестачі та надлишку мелатоніну.

\section{Література}

1. Анисимов В.Н. Мелатонин в организме, применение в клинике / В.Н. Анисимов. - СПб.: Система, 2007. $40 \mathrm{c}$.

2. Барабой В.А. Биоантиоксиданты / В.А. Барабой. - К.: Книга плюс, 2006. - С. 250-257.

3. Березина Т.П. Изменения сократительной активности гастродуоденальной и илеоцекальной зон при стрессе у кроликов / Т.П. Березина, В.И. Овсянников // Бюл. эксперим. биол. и мед. - 2001. - Т. 132, № 8. C. $138-141$.

4. Бондаренко Л.А. Суточные ритмы включения ${ }^{3} \mathrm{H}$-мелатонина в органы гипоталамо-гипофизарнотиреоидной системы у крыс в опытах in vitro / Л.А. Бондаренко, А.Р. Геворкян // Бюлл. эксперим. биол. и мед. - 2007. - Т. 143, № 6. - С. 693-695.

5. Гуралюк В.М. Стрес-індуковані морфофункціональні зміни надниркових залоз за різної довжини фотоперіоду: автореф. дис. на здобуття наук. ступеня канд. мед. наук : спец. 14.03 .04 „Патологічна фізіологія” / Гуралюк Валентин Миколайович: Бук. держ. мед. ун-т МОЗ України. - Одеса, 2008. - 20 с.
6. Добряков Ю.И. Скрининговый метод оценки антистрессорного действия препаратов / Ю.И. Добряков // Стресс и адаптация: Тез. Всесоюзного симпозиума. Кишинев, 1978. - С. 172-173.

7. Ивашкин В.Т. Нарушение резистентности слизистой оболочки желудка и двенадцатиперстной кишки при хроническом гастрите и язвенной болезни / В.Т. Ивашкин, Г.И. Дорофеев // Сов. мед. - 1983. - № 2. C. $10-15$.

8. Отставленные эффекты раннего постнатального введения эпифизарного гормона мелатонина на аудиогенные судороги крыс линии Крушинского-Молодкиной / Т.А.Савина, И.Б.Федотова, И.И. Полетаева [и др.]. // Ж выс. нервной деятельности. - 2005. - Т. 55, № 1. С. $117-125$.

9. Передерій В.Г. Стрес і його наслідки / В.Г. Передерій, М.М. Безюк / Укр. мед. часопис. - 2003. - № 6 (38). C. $65-68$.

10. Пішак В.П. Шишкоподібне тіло і біохімічні основи адаптації / В.П. Пішак. - Чернівці: Медакадемія, 2003. $-152 \mathrm{c}$.

11. Посібник з експериментальних клінічних досліджень в біології та медицині / [Беркало Л.В., Бобович О.В., Гейко О.О. та ін.]. - Полтава, 1997. - 271 с.

12. Про- та антиоксидантна системи і патологічні процеси в організмі людини / О.Г. Резніков, О.М. Полумбрик, Я.Г. Бальон [та ін.] // Вісн. НАН України. - 2014. № $10 .-$ C. $17-29$.

13. Рощін Г.Г. Гострі виразки травного каналу в післяопераційний період у постраждалих із поєднаною травмою / Г.Г. Рощін, В.О. Крилюк // Острые и неотложные состояния в практике врача: научно-практический ж. - К.: Видавничий дім "Здоров'я України", 2009. № 2 (15). - С. 42-44.

14. Стасева И.М. Тактика ведения больных со стрессовыми язвами / И.М. Стасева // Гастроэнтерология. Consilium Medicum. - 2009. - T. 1. - C. 14-17.

15. Цебржинський О.И. Некоторые аспекты антиоксидантного статуса / О.И. Цебржинський // Физиол. и патол. перек. окисл. липидов, гемостаза и иммуногенеза. Полтава, 1992. - С. 122-155.

16. An assau method for anti ulcer substances / F. Pauls, A.M. Wick, E.M. Mac. Key [et al.] // Gastroenterology. 1947. - № 8. - P. 774-782.

17. Halliwell B. Biochemistry of oxidative stress / B. Halliwell // Biochemical Society Transactions. - 2007. Vol. 35, part 5. - P. 1147-1150.

18. Kvetnoy I. M. Extrapineal melatonin: nontraditional localization and possible significance for oncology / Kvetnoy I.M., Yuzhakov V.V. // In: Advances in Pineal Research. - London. - 1994. - Vol. 7. - P. 199-212.

19. Luschak V.I. Free radicals, reactive oxygen species, oxidative stresses and their classifications / V.I. Luschak // Ukr. Biochem. J. - 2015. - Vol. 87, № 6. - P. 11-18.

20. Reiter R.J. Pineal melatonin: cell biology of its synthesis and its physiological interactions / R.J. Reiter // Endocrinol. Rev. - 1991. - Vol. 12. - P. 151-180.

\section{ОКСИДАТИВНЫЙ СТРЕСС В ТКАНЯХ ЖЕЛУДКА КРЫС ПРИ МОДЕЛИРОВАНИИ ГАСТРОПАТИЙ НА ФОНЕ НЕДОСТАТКА И ИЗБЫТКА МЕЛАТОНИНА}

\section{О.А. Цвях, Л.Д. Чеботарь}

Резюме. Исследования показали, что различные модели воздействий на желудок крыс, такие как иммобилизационный стресс и химический гастрит на фоне непродолжительного недостатка и избытка мелатонина вызывают различную реакцию со стороны прооксидантно-антиоксидантной системы (ПАС). При иммобилизационном стрессе мелатонин проявляет гастропротекторное действие, а при моделировании химического гастрита усиливает оксидативный стресс.

Ключевые слова: оксидативный стресс, прооксидантно-антиоксидантная система, желудок, гастропатии, мелатонин. 


\section{OXIDATIVE STRESSES IN RATS' STOMACH TISSUES IN GASTROPATHY SIMULATING UNDER MELATONIN DEFICIENCY OR ITS SURPLUS}

\section{O.O. Tsviakh, L.D. Chebotar}

Abstract. Studies have shown that different models of effects on the stomach of rats, such as immobilization stress and chemical gastritis, against the background of short and excess melatonin causes different reaction of the prooxidantantioxidant system (PAS). In immobilization stress melatonin shows a gastroprotective action, and in simulating chemical gastritis it enhances oxidative stress.

Key words: oxidative stress, prooxidant-antioxidant system, stomach, gastropathy, melatonin.

V.O. Sukhomlynskyi National University (Mykolaiv)

Рецензент - проф. Ю.С Роговий

() О.О. Цвях, Л.Д. Чеботар, 2016
Buk. Med. Herald. - 2016. - Vol. 20, № 3 (79). - P. 190-196

Надійшла до редакції 27.04.2016 року 